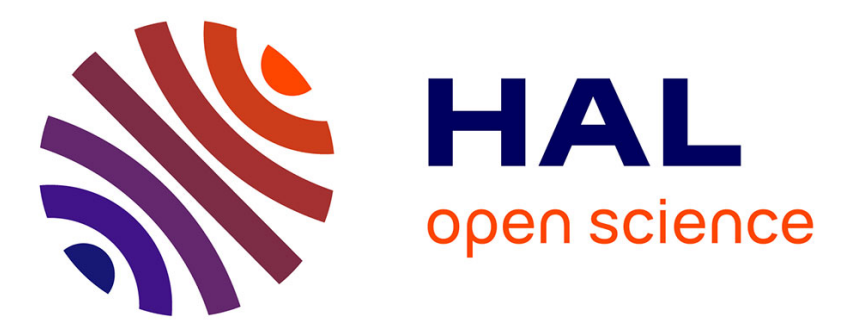

\title{
Combining microsatellites, growth, and adaptive traits for managing in situ genetic resources of Eucalyptus urophylla
}

Vincen Tripiana, Michael Bourgeois, Daniel Verhaegen, Philippe Vigneron, Jean-Marc Bouvet

\section{To cite this version:}

Vincen Tripiana, Michael Bourgeois, Daniel Verhaegen, Philippe Vigneron, Jean-Marc Bouvet. Combining microsatellites, growth, and adaptive traits for managing in situ genetic resources of Eucalyptus urophylla. Canadian Journal of Forest Research, 2007, 37 (4), pp.773-785. cirad-00845388

\section{HAL Id: cirad-00845388 http://hal.cirad.fr/cirad-00845388}

Submitted on 17 Jul 2013

HAL is a multi-disciplinary open access archive for the deposit and dissemination of scientific research documents, whether they are published or not. The documents may come from teaching and research institutions in France or abroad, or from public or private research centers.
L'archive ouverte pluridisciplinaire HAL, est destinée au dépôt et à la diffusion de documents scientifiques de niveau recherche, publiés ou non, émanant des établissements d'enseignement et de recherche français ou étrangers, des laboratoires publics ou privés. 


\title{
Combining microsatellites, growth, and adaptive traits for managing in situ genetic resources of Eucalyptus urophylla
}

\author{
Vincent Tripiana, Michaël Bourgeois, Daniel Verhaegen, Philippe Vigneron, and \\ Jean-Marc Bouvet
}

\begin{abstract}
Genetic diversity and structure of 17 populations representative of the natural range of Eucalyptus urophylla S.T. Blake in Indonesia were analysed with 10 microsatellite markers. Two provenance and progeny trials, using the same populations, were established in the Republic of the Congo and analysed for growth and survival at 37 months. Observed microsatellite heterozygosity $\left(H_{\mathrm{o}}\right)$ was moderate to high within populations $\left(H_{\mathrm{o}}=0.51-0.72\right)$. The index of fixation $\left(F_{\mathrm{IS}}\right)$ was significantly different from zero for all populations $\left(F_{\mathrm{IS}}=0.13-0.31\right)$ and possibly resulted from a Wahlund effect. The differentiation parameter was low $\left(F_{\mathrm{ST}}=0.04\right)$ and not significantly different from zero, which can be explained by effective gene flow via pollen. The genetic variances within and among provenances for survival and growth traits were significantly different from zero, representing $13 \%-23 \%$ and $14 \%-50 \%$ of the total variation, respectively. The differentiation between populations based on quantitative traits was marked $\left(Q_{\mathrm{ST}}=0.07-0.33\right)$. A negative relationship between altitude of the seed source and its performance in the Congo was observed $\left(R^{2}=0.59-0.67\right)$ and could be explained by the effect of natural selection along the altitudinal gradient. This marked differentiation for quantitative traits despite high apparent gene flow results in a clinal variation, which suggests the use of altitude of seed source as an important principle for in situ or ex situ management of E. urophylla genetic resources.
\end{abstract}

Résumé : À l'aide de 10 marqueurs microsatellites, les auteurs ont analysé la diversité et la structure génétiques de 17 populations représentatives de l'aire naturelle d'Eucalyptus urophylla S.T. Blake en Indonésie. La croissance et la survie après 37 mois ont été analysées dans deux essais établis en République du Congo et contenant les mêmes provenances et descendances. L'hétérozygotie observée $\left(H_{\mathrm{O}}\right)$ chez les marqueurs microsatellites variait de modérée à élevée au sein des populations $\left(H_{\mathrm{O}}=0,51-0,72\right)$. L'indice $F_{\mathrm{IS}}$ était significativement différent de zéro pour toutes les populations $\left(F_{\mathrm{IS}}=\right.$ $0,13-0,31)$ et était possiblement le résultat d'un effet de Wahlund. La différenciation de population était faible $\left(F_{\mathrm{ST}}=\right.$ $0,04)$ et n'était pas significativement différente de zéro, ce qui peut s'expliquer par un flux génique efficace attribuable au pollen. Les variances génétiques au sein et parmi les provenances pour les caractères de survie et de croissance étaient significativement différentes de zéro, représentant respectivement $13 \%$ à $23 \%$ et $14 \%$ à $50 \%$ de la variation totale. La différenciation de population estimée à partir des caractères quantitatifs était élevée, avec une valeur de $Q_{\mathrm{ST}}=0,07-0,33$. Une relation négative entre l'altitude des sources de semences et leur performance au Congo a été remarquée $\left(R^{2}=0,59-\right.$ 0,67). Cette relation pourrait s'expliquer par l'effet de la sélection naturelle le long du gradient altitudinal. Cette différenciation marquée chez les caractères quantitatifs, en dépit d'un flux génique apparent élevé, se manifeste par un patron de variation clinale, ce qui indique que l'altitude des sources de semences est un critère important qui devrait être utilisé pour la gestion in situ et ex situ des ressources génétiques d'E. urophylla.

[Traduit par la Rédaction]

\section{Introduction}

During recent decades, the genetic resources of many forest tree species have been explored largely to supply the plantation programme with adequate material and to define strategies for in situ or ex situ management (Kleinschmit et al. 2004; Ducousso et al. 2004). For economically important species, provenance and progeny trials were established to select the best seed sources for plantation on the basis of adaptive and economic traits (i.e., survival, growth, and wood properties).

The genetic resources of tree species currently can be better explored and conserved by combining a variety of tools such as molecular markers and quantitative traits (Bekessy

Received 17 November 2005. Accepted 28 September 2006. Published on the NRC Research Press Web site at cjfr.nrc.ca on 15 June 2007.

V. Tripiana, D. Verhaegen, P. Vigneron, and J.-M. Bouvet. ${ }^{1}$ Centre de coopération internationale en recherche agronomique pour le développement (CIRAD), Biological System Department, Research Unit "Genetic Diversity and Breeding of Forest Tree Species" TA 10C, Campus International de Baillarguet, 34398 Montpellier CEDEX, France.

M. Bourgeois. Institute National de la Recherche Agronomique, research unit "Génétique et Ecophysiologie des légumineuses à graines" (URLEG) BP 86510, F-21065 Dijon, France.

${ }^{1}$ Corresponding author (e-mail: jean-marc.bouvet@cirad.fr). 
et al. 2003; Cavers et al. 2004). On the one hand, neutral molecular markers give information about the impact of evolutionary forces, such as drift, mutation, and migration, and about the mating system of the species. On the other hand, quantitative traits related to adaptation and fitness are informative about the impact of natural selection.

Although the results provided by neutral molecular markers are not directly related to the information provided by adaptive traits and many studies have demonstrated that they are not good predictors of adaptive diversity (Frankham et al. 2002), they can give useful information on the extent of differentiation among populations and can suggest the presence of "hidden genetic variability" that may be useful in future conservation and breeding efforts. This hidden variation can be potentially useful for facing future environmental changes, e.g., in abiotic conditions and emergence of new parasites.

Examples of studies combining molecular and quantitative approaches can be found for the conservation and management of forest genetic resources of some temperate species (Kleinschmit et al. 2004; Ducousso et al. 2004). However, these studies are still limited in tropical forest trees, including species that play an important role in the wood economy and that suffer marked degradation in their natural range. This is the case for Eucalyptus urophylla S.T. Blake, a very important species in the tropical zone. This species has mainly been used to create interspecific hybrids for commercial clonal forest plantations, because it shows very good adaptation to the humid tropical climate and its wood is suitable for the pulp industry (Vigneron and Bouvet 1997). Many provenances collected in the natural range of E. urophylla were introduced in tropical countries to start genetic improvement programmes (Eldridge et al. 1993). Initially, analyses were conducted using quantitative traits only to rank provenances according to adaptive and growth performance criteria and to determine the best genotypes to include in the breeding population. However, few results are available to help us understand the distribution of genetic variation within the natural range of the species, although urgent measures need to be taken for in situ conservation.

In this study, we aimed to advance our understanding of the in situ variation of E. urophylla by combining microsatellite data and quantitative traits related to adaptation and growth. Our objectives were $(i)$ to analyse the genetic diversity and structure of $E$. urophylla populations using microsatellite markers, (ii) to assess the genetic variances within and among the populations for adaptive and growth traits using a controlled experimental design, (iii) to evaluate the effect of abiotic factors present in the natural range of the species on genetic variation, and (iv) to define principles for in situ management of genetic resources for future application in breeding programmes or for the development of a conservation strategy.

\section{Materials and methods}

\section{Characteristics of $\boldsymbol{E}$. urophylla}

Eucalyptus urophylla is a forest tree usually reaching 25$45 \mathrm{~m}$ in height and up to $1 \mathrm{~m}$ in diameter at breast height. It is a long-lived savannah tree species (over 200 years). Its natural range extends in the eastern part of Indonesia and Timor Leste in the Sunda archipelago $\left(122^{\circ}-127^{\circ} \mathrm{E}, 8^{\circ}-\right.$ $10^{\circ} \mathrm{S}$ ) across seven islands within an area of $500 \mathrm{~km}$ (east to west) by $200 \mathrm{~km}$ (north to south) (Fig. 1). The species occurs over a wide altitudinal range (sea level to $3000 \mathrm{~m}$ ) and over a wide range of climatic conditions with a dry season varying from about 2 months to 8 months. It is found on mountain slopes and in valleys on different types of soils. Population densities vary greatly according to land use, localities, and ecological conditions. It reproduces mostly sexually and is mainly insect and bird pollinated. It fruits abundantly. The species is mainly barochorous (fruits are mainly disseminated by gravity); however, as for other $\mathrm{Eu}$ calyptus species, its seeds are also likely to be dispersed by animals, such as birds and bats (House 1997).

\section{Population sampling in the natural range}

Based on the seed collection made by Martin and Cossalter (1976a, 1976b, 1976c), 17 populations (the term population is used as the traditional definition in population genetics) were identified as representative of the natural distribution of the species covering several islands, several locations per island, and different altitudes (Fig. 1, Table 1).

Within each main population, 1-19 subpopulations were sampled according to the altitudinal gradient; these subpopulations correspond to the provenances defined by Martin and Cossalter $(1976 a, 1976 b, 1976 c)$. One to 95 adult trees were randomly sampled in each subpopulation (depending on the size and the accessibility), and seeds were collected from each mother tree. A minimum distance of $50 \mathrm{~m}$ between individual trees was used to avoid selection of closely related individuals. The main characteristics of the populations and subpopulations are given in Table 1.

\section{Provenance and progeny trials and quantitative trait measurement}

Seeds collected in the natural range were sown in the nursery in the Republic of Congo from July to September 1973 in polybags $(20 \mathrm{~cm}$ high, $10 \mathrm{~cm}$ diameter) containing adequate media (one-third sand, one-third forest soil, and one-third compost). Five months after sowing, the seedlings were planted in a provenance and progeny trial in two locations of the southern region of the Congo: Loudima in the Niari Valley $\left(4^{\circ} 11^{\prime} \mathrm{S}, 13^{\circ} 50^{\prime} \mathrm{E}\right.$, altitude $165 \mathrm{~m}$, mean annual temperature of $26{ }^{\circ} \mathrm{C}$, a mean annual rainfall of $1080 \mathrm{~mm}$ ) and Pointe-Noire $\left(4^{\circ} 45^{\prime} \mathrm{S}, 12^{\circ} 00^{\prime} \mathrm{E}\right.$, altitude $80 \mathrm{~m}$, mean annual temperature of $25{ }^{\circ} \mathrm{C}$, and mean annual rainfall of $1250 \mathrm{~mm}$ ) along the Atlantic coast. Soils are mainly sandy in Pointe-Noire, whereas they are clay in Loudima.

In Loudima, a randomized complete block design with two replications was established with 25 trees of the same family per plot. In each block, the populations were randomized, and the family were randomized within each population. In Pointe-Noire, the field design allowed only one replication, with plots containing 10-50 trees of the same family. Three hundred and twelve families were common to both field trials and were subsequently used for quantitative analyses. The number of families varied according to the population and subpopulation from 4 to 95 , and the number of individuals per population varied from 100 to 4400 
Fig. 1. Location of 17 natural populations of Eucalyptus urophylla in seven islands of the Sunda archipelago.

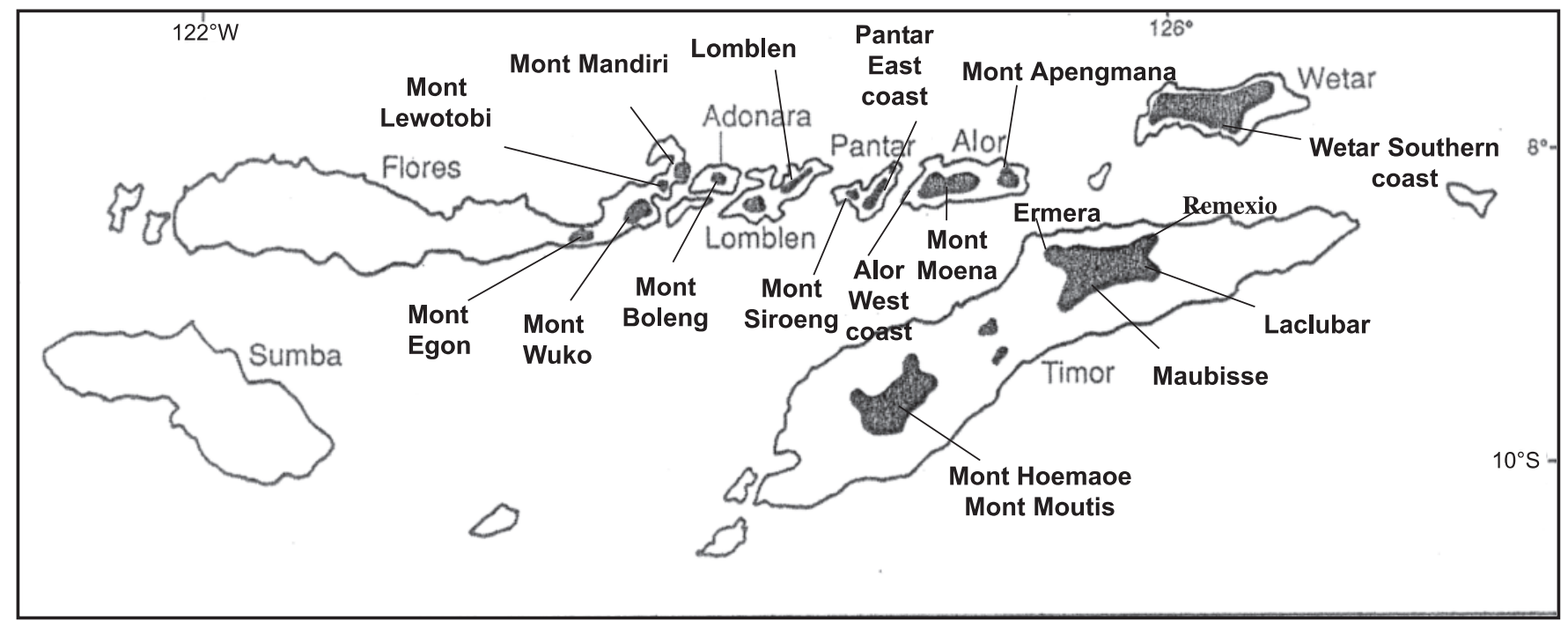

(Table 1). In each site, the density of planting was 1600 trees $\cdot h^{-1}$.

At 37 months, the percent survival was calculated. Growth traits such as height $(\mathrm{m})$, circumference at breast height $(\mathrm{cm})$ and basal area $\left(\mathrm{m}^{2} \cdot \mathrm{ha}^{-1}\right)$ were also measured and calculated to differentiate the provenances.

\section{Population sample for molecular analysis}

For molecular analysis, leaves were not collected from the field trials in the Congo. In Pointe-Noire, the trial was selectively thinned in 1984 at age 132 months $(50 \%$ of the trees were cut). The remaining trees represented a biased sample of the natural population that was not suitable for population genetic analyses. In Loudima, the trials were not thinned, but the trees were very tall (30-40 m high) and collection of leaves was very difficult. It was then decided to collect leaves on young seedlings using the same seedlots as in the provenance and progeny trials. In 2003, seeds from a larger sample of the natural range (including the islands of Alor, Wetar, Pantar, and Lomblen) were sown in adequate substrate in the nursery in Montpellier, France (Table 1). A larger set of populations for molecular analyses (16 populations) than for quantitative analyses in field trial (11 populations) was used to estimate population genetic parameters of a more representative sample of the natural range of E. urophylla.

Two months after sowing, five leaves were collected from each seedling and dried using silica gel. The number of subpopulations, families, and individuals for molecular analyses are given for each population in Table 1. To have an efficient sample size at the population level, two seedlings were sampled from each family. The number of individuals per population ranged from 9 (Mont Hoemaoe Moutis) to 34 (Mont Apengmana).

\section{DNA extraction and microsatellite analysis}

DNA was extracted from dried leaves following the Matab method (Bousquet et al. 1990). DNA was isolated from an average of two individuals per family (Table 1).

Microsatellite markers were used to detect the natural variability at the molecular level. Ten polymorphic nuclear loci were used to screen the sampled populations: EMBRA18, EMBRA32, EMBRA33, EMBRA44, EMBRA52, EMBRA63, EMBRA64 (Brondani et al. 1998), FMRSA1, FMRSA4, and FMRSA5 (Van der Nest et al. 2000). Microsatellite loci were amplified using PCR in a $15 \mu \mathrm{L}$ reaction volume containing $25 \mathrm{ng}$ of genomic DNA in a $1 \times$ reaction buffer $(10 \mathrm{mmol} / \mathrm{L}$ Tris- $\mathrm{HCl}, 50 \mathrm{mmol} / \mathrm{L} \mathrm{KCl}, 2 \mathrm{mmol} / \mathrm{L}$ $\mathrm{MgCl}_{2}$ ), $0.2 \mathrm{mmol} / \mathrm{L} \mathrm{dNTPs}, 0.10 \mu \mathrm{mol} / \mathrm{L}$ of forward primer, $0.06 \mu \mathrm{mol} / \mathrm{L}$ of reverse primer, $0.10 \mu \mathrm{mol} / \mathrm{L}$ of the infrared (IR) dye IRdye M13/700 or M13/800, and $0.13 \mathrm{U} / \mu \mathrm{L}$ Taq $\left(1 \mathrm{U} \approx 16.67\right.$ nkat) DNA polymerase (Invitrogen $\left.{ }^{\mathrm{TM}}\right)$ ). The amplifications were carried out with a Stratagene ${ }^{\circledR}$ Robocycler gradient 96 thermal cycler under the following conditions: denaturation at $94{ }^{\circ} \mathrm{C}$ for $4 \mathrm{~min}$; 30 cycles of denaturation at $94{ }^{\circ} \mathrm{C}$ for $30 \mathrm{~s}$, annealing at $51{ }^{\circ} \mathrm{C}$ for $45 \mathrm{~s}$, and extension at $72{ }^{\circ} \mathrm{C}$ for $45 \mathrm{~s}$; and a final extension at $72{ }^{\circ} \mathrm{C}$ for $5 \mathrm{~min}$. The reverse PCR primers were probed with a 19 base extension at its $5^{\prime}$ tail end with the sequence 5'-CACGACGTTGTAAAACGAC-3'. This sequence is complementary to an IR-labelled universal M13 forward sequencing primer, which is included in the PCR reaction. During PCR, the tailed primer generates a complementary sequence that is subsequently utilized for priming in the amplification reaction, thereby generating IR-labelled PCR products. The samples were electrophoresed on an IR DNA analyser (Li-Cor, Inc., Lincoln, Nebraska), which can detect primer-labelled extension products at two different wavelengths (IRDye $700 \mathrm{~nm}$ and IRDye $800 \mathrm{~nm}$ ). This allowed loading of a multiplex of four PCR products in one well. The individuals were genotyped using SagaGT software (Li-Cor, Inc., Lincoln, Nebraska).

\section{Molecular genetic data analysis}

To eliminate bias in genetic structure parameter estimates owing to the sampling of two individuals from each family, estimation of population genetic parameters and statistical tests were first conducted considering a single individual per family, i.e., on two subsamples. The mean of both estimates was then calculated. Because the estimates of genetic parameters between the pooled sample (with two individuals 
Table 1. Characteristics of the 17 natural populations of E. urophylla (Martin and Cossalter 1976a, 1976b, 1976c) with details on population identification and the number of subpopulations and families used in the provenance and progeny trial in the Congo and in the samples used for molecular marker analyses.

\begin{tabular}{|c|c|c|c|c|c|c|c|c|c|c|c|}
\hline \multirow[b]{2}{*}{ Island } & \multirow[b]{2}{*}{$\begin{array}{l}\text { Population } \\
\text { identification }\end{array}$} & \multirow[b]{2}{*}{$\begin{array}{l}\text { Latitude } \\
\text { (S) }\end{array}$} & \multirow[b]{2}{*}{$\begin{array}{l}\text { Longitude } \\
\text { (E) }\end{array}$} & \multirow[b]{2}{*}{$\begin{array}{l}\text { Altitude } \\
(\mathrm{m})\end{array}$} & \multirow[b]{2}{*}{ Rainfall (mm) } & \multicolumn{3}{|c|}{ Field experiment in the Congo } & \multicolumn{3}{|c|}{ Molecular analysis } \\
\hline & & & & & & Subpopulation $^{a}$ & $\begin{array}{l}\text { Families/ } \\
\text { population }^{b}\end{array}$ & $\begin{array}{l}\text { Total } \\
\text { individuals/ } \\
\text { population }^{c}\end{array}$ & Subpopulation & $\begin{array}{l}\text { Families/ } \\
\text { population }\end{array}$ & $\begin{array}{l}\text { Total } \\
\text { individuals/ } \\
\text { population }\end{array}$ \\
\hline Adonara & Mont Boleng & $8^{\circ} 30^{\prime}$ & $123^{\circ} 29^{\prime}$ & 695 & 950 & $2(2)$ & $4(4)$ & $125(100)$ & 1 & 15 & 28 \\
\hline \multirow[t]{3}{*}{ Alor } & Mont Apengmana & $8^{\circ} 17^{\prime}$ & $124^{\circ} 45^{\prime}$ & $475-900$ & - & - & - & - & 4 & 19 & 34 \\
\hline & Mont Moena & $8^{\circ} 17^{\prime}$ & $124^{\circ} 37^{\prime}$ & $550-950$ & $1200-1400$ & - & - & - & 4 & 17 & 28 \\
\hline & West Coast Alor & $8^{\circ} 22^{\prime}$ & $124^{\circ} 26^{\prime}$ & $350-550$ & $1200-1400$ & - & - & - & 3 & 14 & 25 \\
\hline \multirow[t]{4}{*}{ Flores } & Mont Egon & $8^{\circ} 40^{\prime}$ & $122^{\circ} 26^{\prime}$ & $425-700$ & $1200-1500$ & $3(2)$ & $15(15)$ & $725(375)$ & 3 & 14 & 23 \\
\hline & Mont Lewotobi & $8^{\circ} 32^{\prime}$ & $122^{\circ} 46^{\prime}$ & $480-600$ & $1200-1500$ & $2(2)$ & $10(10)$ & $500(250)$ & 3 & 17 & 29 \\
\hline & Mont Mandiri & $8^{\circ} 15^{\prime}$ & $122^{\circ} 57^{\prime}$ & $600-800$ & 1250 & $2(2)$ & $6(5)$ & $225(125)$ & 2 & 15 & 24 \\
\hline & Mont Wuko & $8^{\circ} 33^{\prime}$ & $122^{\circ} 34^{\prime}$ & $750-1070$ & 1350 & $3(2)$ & $15(15)$ & $675(375)$ & 3 & 12 & 21 \\
\hline Lomblen & Lomblen & $8^{\circ} 25^{\prime}$ & $123^{\circ} 29^{\prime}$ & $520-910$ & 950 & $4(4)$ & $15(18)$ & $825(450)$ & 5 & 11 & 20 \\
\hline \multirow[t]{2}{*}{ Pantar } & Mont Siroeng & $8^{\circ} 27^{\prime}$ & $124^{\circ} 60^{\prime}$ & 600 & $600-800$ & - & - & - & 1 & 10 & 16 \\
\hline & East Coast Pantar & $8^{\circ} 22^{\prime}$ & $124^{\circ} 12^{\prime}$ & $475-600$ & $900-1000$ & - & - & - & 2 & 11 & 20 \\
\hline \multirow[t]{5}{*}{ Timor } & Laclubar & $8^{\circ} 46^{\prime}$ & $125^{\circ} 34^{\prime}$ & 890-1375 & $1750-2050$ & $12(12)$ & $52(52)$ & $2200(1300)$ & 4 & 13 & 23 \\
\hline & Maubisse & $8^{\circ} 52^{\prime}$ & $125^{\circ} 35^{\prime}$ & $1200-1900$ & $1550-2150$ & $12(12)$ & $55(57)$ & $2300(1425)$ & 5 & 16 & 27 \\
\hline & Mont Hoemaoe Moutis & $9^{\circ} 65^{\prime}$ & $123^{\circ} 50^{\prime}$ & $1125-1630$ & $1500-1850$ & $6(6)$ & $27(27)$ & $1200(675)$ & 3 & 9 & 9 \\
\hline & Remexio & $8^{\circ} 40^{\prime}$ & $125^{\circ} 39^{\prime}$ & $800-1150$ & $1350-1900$ & $19(19)$ & $95(95)$ & $4400(2375)$ & 4 & 15 & 20 \\
\hline & Ermera & $8^{\circ} 39^{\prime}$ & $125^{\circ} 28^{\prime}$ & 500 & $1800-2500$ & $4(4)$ & $15(15)$ & $650(375)$ & - & - & - \\
\hline Wetar & South Coast Wetar & $7^{\circ} 54^{\prime}$ & $126^{\circ} 26^{\prime}$ & $300-350$ & $700-1300$ & - & - & - & 2 & 10 & 13 \\
\hline Total $^{d}$ & & & & & & $69(67)$ & $308(312)$ & $13825(7825)$ & 49 & 208 & 360 \\
\hline
\end{tabular}

${ }^{a}$ Number of subpopulations within the population at the forest stations of Loudima and Pointe-Noire (in parentheses)

${ }^{b}$ Number of families within population at the forest stations of Loudima and Pointe-Noire (in poarentheses).

${ }^{c}$ Number of individuals within population at the forest stations of Loudima and Pointe-Noire (in parentheses).

${ }^{d}$ Total number of subpopulations, families, and individuals in the field trial in Loudima and Pointe-Noire (in parentheses) and in the molecular analysis. 
per family) and the separate subsamples did not differ significantly, it was decided to present the results of the pooled sample only.

The standard genetic diversity parameters were determined for each population by using GENETIX version 4.05 (Belkhir et al. 1996-2004). The observed number of alleles $\left(n_{\mathrm{a}}\right)$, the observed heterozygosity $\left(H_{\mathrm{o}}\right)$ (Nei 1987), and the index of fixation $\left(F_{\mathrm{IS}}\right)$ using the estimators of Weir and Cockerham (1984) were calculated. To test for heterozygote deficiency relative to Hardy-Weinberg expectations, alleles were permuted among individuals within population samples and $F_{\text {IS }}$ was used as a statistic for comparison. Wright's $F_{\text {ST }}$ statistics (Wright 1951) was estimated for the global subpopulations and all population pairs by a "weighted" analysis of variance (Weir and Cockerham 1984). To investigate the relationship between genetic distances measured by pairwise $F_{\mathrm{ST}}$ and geographic distances, we calculated the coefficient of correlation $(r)$ and performed a Mantel test (Mantel 1967).

To illustrate the differentiation between populations, a distance tree was constructed using PHYLIP version 3.65 (Felsenstein 1993). Pairwise genetic distances between pairs of populations were computed using Cavalli-Sforza's chord measure (Cavalli-Sforza and Edwards 1967), obtained from the GENDIST program of PHYLIP. The tree was constructed with the neighbour-joining method of Saitou and Nei (1987) using the NEIGHBOR program. The robustness of each node was evaluated by bootstrapping data over loci for 1000 replications using the SEQBOOT program version 6 and the consensus tree obtained by CONSENSE was displayed with TREEVIEW software (Page 1996).

\section{Quantitative data analysis}

The number of families per population and the number of individuals per family varied in the field experiments. Missing families and individuals reduce the degrees of freedom and the precision of the estimates, because the variance is inversely related to the degrees of freedom. In severely unbalanced situations, such as those regularly found in forest tree genetic experiments, maximum likelihood estimates provide superior estimators compared with least squares estimators (Searle et al. 1992). As a consequence, the variance components were estimated using the SAS ${ }^{\circledR}$ VARCOMP procedure and the restricted maximum likelihood method of the SAS/STAT ${ }^{\circledR}$ software (SAS Institute Inc. 1990) using mixed model 1: $y_{i j k l}=\mu+s_{i}+p_{j}+p \times s_{i j}+f(p)_{k(j)}+s \times$ $f(p)_{i k(j)}+r_{i j k l}$, where $y_{i j k l}$ is the lth plot in the $k$ th family sampled in the $j$ th population in the $i$ th site; $\mu$ is the overall mean; $s_{i}$ is the effect of site $i$ considered as a fixed effect; $p_{j}$ is the random effect of the $j$ th population, with variance of $\sigma_{p}^{2}$ and mean $0 ; p \times s_{i j}$ is a random effect of the site by population interaction, with variance of $\sigma_{p \times s}^{2}$ and mean $0 ; f(p)_{k(j)}$ is the random effect of the $k$ th family of the $j$ th population, with variance of $\sigma_{f}^{2}$ and mean $0 ; s \times f(p)_{i k(j)}$ is a random effect of the site by family interaction, with variance of $\sigma_{s \times f}^{2}$ and mean 0 ; and $r_{i j k l}$ is the residual random effect with variance of $\sigma_{r}^{2}$ and mean 0 . To reduce the scale effect in the analysis of interaction, the growth data were log-transformed.

All terms were tested with the appropriate error variance; site and population were tested over the site by population interaction. The site by population interaction and the family were tested over the site by family interaction mean square. The site by family interaction was tested over the full model error term.

Various variance ratios were calculated by the ratio of the variance components over total variance, for example for the population effect: $R=\sigma_{p}^{2} /\left(\sigma_{p}^{2}+\sigma_{p \times s}^{2}+\sigma_{s \times f}^{2}+\sigma_{r}^{2}\right)$.

Regression analyses were performed using Xlstat-Pro ${ }^{\circledR}$ version 7.5 (Addinsoft France, Paris; www.xlstat.com) to explain the relationship between performance of the subpopulations in the conditions of the Congo and the abiotic variables such as altitude and rainfall of the source population in Indonesia. Linear and parabolic models were tested using the determination coefficient $\left(R^{2}\right)$. We used the performance of each subpopulation, which was located at a specific altitude, rather than the performance of each population, which was distributed over a large altitudinal range (Table 1).

To group the subpopulations according to their performance in the field, we used a hierarchical cluster analysis with Xlstat-pro version 7.5 (Addinsoft France, Paris; www. xlstat.com). The distance between two subpopulations was defined as the Euclidean norm of the difference between the two centred and scaled vectors of their characteristics (height, circumference, and percent survival). The dissimilarity between clusters based on this distance was defined using Ward's method (Ward 1963). The number of groups to build was chosen by visual inspection of the cluster dendrogram.

\section{Comparison of molecular and quantitative data}

Direct comparison of variation of quantitative traits with genetic variation at multiple unlinked gene or marker loci is made possible by the theoretical relationship between the multiple loci $F_{\mathrm{ST}}$ and the partitioning of genetic variation in quantitative traits $Q_{\mathrm{ST}}$. This parameter is defined as $Q_{\mathrm{ST}}=\sigma_{\mathrm{gbp}}^{2} /\left(\sigma_{\mathrm{gbp}}^{2}+2 \sigma_{\mathrm{gwp}}^{2}\right)$, where $\sigma_{\mathrm{gbp}}^{2}$ is the genetic variance between populations and $\sigma_{\mathrm{gwp}}^{2}$ is the genetic variance within populations (McKay and Latta 2002). It is assumed that variance among and within populations is mainly due to additive effects. When $Q_{\mathrm{ST}}$ and $F_{\mathrm{ST}}$ are equal (i.e., population differentiation in the quantitative trait is equal to that predicted from unlinked gene or marker loci), genetic drift is likely to be the main cause of differentiation. When $F_{\mathrm{ST}}$ is lower or higher than $Q_{\mathrm{ST}}$, then selection is acting on quantitative traits; the molecular markers used to estimate $F_{\mathrm{ST}}$ were considered to be neutral. The variance $\sigma_{\mathrm{gbp}}^{2}$ was estimated as $\sigma_{p}^{2}$. In the field experiments in Pointe-Noire and Loudima, the effect of environment was controlled (in the field trial), and we assumed that the phenotypic variance between populations was close to the genetic variance. The variance $\sigma_{\mathrm{gwp}}^{2}$ was estimated using $\sigma_{f}^{2}$, with the assumption that genetic variance is mainly due to additive variance $\sigma_{\mathrm{gwp}}^{2}=4 \sigma_{f}^{2}$ (assuming that all families are open-pollinated by unrelated fathers). Standard error of $Q_{\mathrm{ST}}$ was calculated according to the Dickerson method (Dickerson 1969 cited in Becker 1984).

The values of $F_{\mathrm{ST}}$ and $Q_{\mathrm{ST}}$ were compared according to 
Table 2. Genetic diversity parameters and fixation index of 16 natural populations of E. urophylla estimated from 10 microsatellite loci data on the 16 populations.

\begin{tabular}{lrlrl}
\hline Population identification & $N$ & $H_{\mathrm{o}}$ & \multicolumn{1}{c}{$n_{\mathrm{a}}$} & \multicolumn{1}{l}{$F_{\text {IS }}$} \\
\hline Mont Boleng & 28 & $0.66(0.13)$ & 8.2 & $0.16(0.06$ to 0.22$)$ \\
Mont Apengmana & 34 & $0.60(0.17)$ & 10.6 & $0.24(0.14$ to 0.29$)$ \\
Mont Moena & 28 & $0.70(0.18)$ & 10.1 & $0.13(0.06$ to 0.17$)$ \\
West coast Alor & 25 & $0.63(0.16)$ & 8.4 & $0.17(0.07$ to 0.23$)$ \\
Mont Egon & 23 & $0.52(0.17)$ & 8.0 & $0.31(0.17$ to 0.31$)$ \\
Mont Lewotobi & 29 & $0.54(0.14)$ & 7.9 & $0.29(0.17$ to 0.31$)$ \\
Mont Mandiri & 24 & $0.57(0.26)$ & 8.4 & $0.23(0.16$ to 0.33$)$ \\
Mont Wuko & 21 & $0.58(0.28)$ & 7.7 & $0.23(0.14$ to 0.27$)$ \\
Lomblen & 20 & $0.62(0.18)$ & 7.5 & $0.14(0.04$ to 0.19$)$ \\
Mont Siroeng & 16 & $0.52(0.19)$ & 5.2 & $0.20(0.04$ to 0.28$)$ \\
East coast Pantar & 20 & $0.54(0.16)$ & 5.5 & $0.22(0.11$ to 0.31$)$ \\
Laclubar & 23 & $0.64(0.15)$ & 8.1 & $0.21(0.10$ to 0.26$)$ \\
Maubisse & 27 & $0.66(0.13)$ & 9.3 & $0.15(0.06$ to 0.20$)$ \\
Mont Hoemaoe Moutis & 9 & $0.51(0.26)$ & 5.6 & $0.27(-0.06$ to 0.37$)$ \\
Remexio & 20 & $0.72(0.15)$ & 9.7 & $0.18(0.06$ to 0.25$)$ \\
South coast Wetar & 13 & $0.62(0.14)$ & 7.0 & $0.23(0.06$ to 0.32$)$ \\
\hline
\end{tabular}

Note: $N$, population size; $n_{\mathrm{a}}$, observed number of alleles (mean per marker loci); $H_{\mathrm{o}}$, observed heterozygosity, with SD given in parentheses; $F_{\mathrm{IS}}$, fixation index, with $95 \%$ CI given in parentheses.

an adapted method described by Saint-Laurent et al. (2003) by performing an analysis of variance using each trait $Q_{\mathrm{ST}}$ and each locus $F_{\mathrm{ST}}$ estimate as a repeat.

\section{Results}

\section{Population diversity and differentiation based on microsatellite markers}

All the marker loci were polymorphic in all populations. The total number of alleles across populations varied among loci from 10 (FMRSA4) up to 29 (EMBRA 52) with a mean of 20.7 for the total population.

Diversity parameters (Table 2), such as $H_{\mathrm{o}}$ displayed moderate variation among populations with values ranging from 0.51 for Mont Hoemaoe Moutis to 0.72 for Remexio. The same pattern was noted for the $n_{\mathrm{a}}$, which was high and ranged from 5.2 for Mont Siroeng to 10.6 for Mont Apengmana. The values of $F_{\text {IS }}$ varied among populations from 0.14 for Lomblen to 0.33 for Mont Egon. They were all significantly different from $0(P<0.001$; Table 2$)$, suggesting departure from Hardy-Weinberg equilibrium. The same conclusion was drawn for the entire population for which $F_{\mathrm{IS}}=$ $0.20(P<0.0001)$.

Weir and Cockerham's (1984) differentiation estimate was low, $F_{\mathrm{ST}}=0.04$ for the set of the 16 populations. It was significantly different from $0(P<0.001)$, which is evidence of low differentiation among populations in the natural range. This pattern of differentiation among populations was illustrated by the unrooted neighbour-joining tree (Fig. 2). It exhibited only three clusters with bootstrap values higher than 500. One cluster included two populations located in different islands, but the distance separating these two populations is less than $20 \mathrm{~km}$.

Using the 10 populations common to molecular and field trial analyses (Table 1), the differentiation parameter, $F_{\mathrm{ST}}=$ 0.035 , was significantly different from $0(P<0.0001)$. This value was similar to that estimated with the total population, although six populations were removed from this sample.
The Mantel test did not show a significant correlation between the matrix of pairwise $F_{\mathrm{ST}}$ and the matrix of geographic distance for both samples. The coefficients of correlation was low and was not significantly different from $0, r=0.10(P=0.38)$, showing that the populations did not follow the model of isolation by distance.

\section{Performances of $E$. urophylla in field trials in the Congo}

The performance of $E$. urophylla in the Congo differed markedly between the two sites (Table 3 ). In the Loudima forest station, individual height, circumference, and basal area were significantly higher, because soil conditions are better than in Pointe-Noire. This better growth resulted in smaller variation within the trial as shown by the coefficient of variation.

This difference in site quality resulted in a significant population by site interaction for all traits and for both types of sampling (Table 4). However, the rate of survival presented a nonsignificant site by population interaction for the sample based on the 10 common populations. The interaction was attributed to changes in ranking, the analyses of variance being conducted with data transformed by a logarithm function that reduces the scale effect. This was confirmed by the significant values of the rank coefficient of correlation between the populations established in PointeNoire and those established in Loudima. For height, circumference, individual basal area, and survival, the estimates were $0.92,0.76,0.61$, and 0.83 , respectively.

With the total sample (11 populations), the analysis of variance showed that substantial genetic variation for growth and adaptive traits was present for E. urophylla across populations and families. The ratio of variance among populations to total variance ranged from $14 \%$ for survival to $43 \%$ for height growth. The percent variance explained by the family effect was generally smaller, with values ranging from $12 \%$ to $24 \%$ (Table 4 ).

The values of $Q_{\mathrm{ST}}$ were above 0.15 , except for basal area, 
Fig. 2. Unrooted neighbour-joining tree drawn with PHYLIP version 6.1 (Felsenstein 1993) with the matrix of genetic distances calculated using the Cavalli-Sforza distance (Cavalli-Sforza and Edwards 1967). Values at the base of the branches correspond to the bootstrap values after 1000 replications.

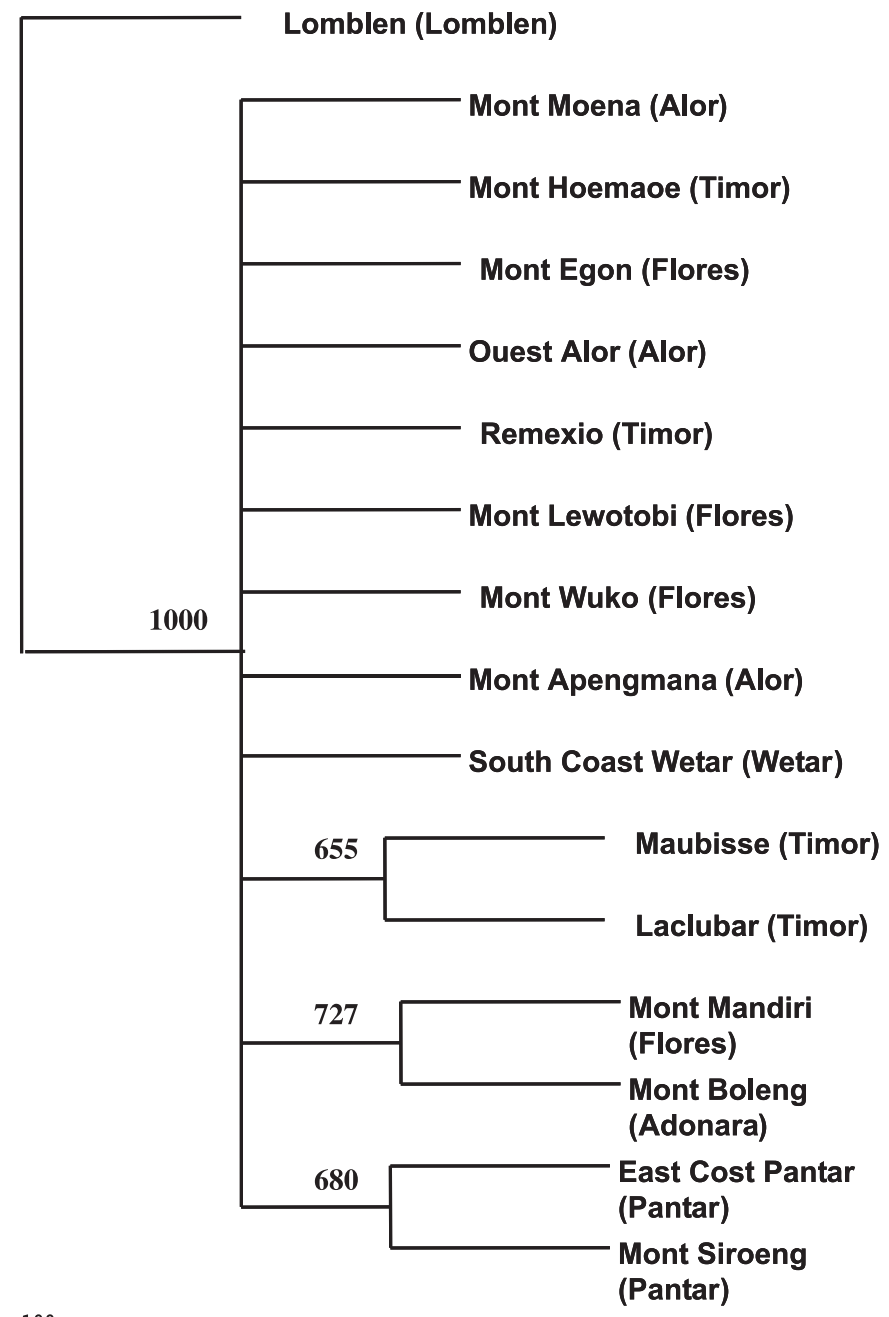

$\underline{100}$

and the SE was smaller than the absolute value. The high $Q_{\mathrm{ST}}$ demonstrated the presence of additive genetic variance among the populations. The $Q_{\mathrm{ST}}$ values were higher than the $F_{\mathrm{ST}}$ assessed with molecular markers. The mean values $\left(Q_{\mathrm{ST}}=0.21\right.$ and $\left.F_{\mathrm{ST}}=0.04\right)$ were significantly different (ANOVA, $P=0.0001$ ).

Based on the sample common to the field and molecular analyses (10 populations), the percent variance changed, but its distribution among the different effects exhibited the same trend (Table 4). For height, circumference, and basal area, the $Q_{\mathrm{ST}}$ values were higher than estimates obtained with the total sample $\left(Q_{\mathrm{ST}}=0.68, Q_{\mathrm{ST}}=0.22\right.$, and $Q_{\mathrm{ST}}=$ 0.37, respectively), whereas it was smaller for survival $\left(Q_{\mathrm{ST}}=0.02\right)$. These changes were expected, because the sampling sizes were very different between the two approaches.

\section{Relationship between field performance and altitude of seed source}

The adaptation and growth of the species in the Congo were strongly related to the abiotic variables characterizing environment in the natural range. This is illustrated in Fig. 3, which presents the relationship between performances in the Congo versus altitude of the seed source. A strong negative correlation was noted between growth traits (height and circumference) and altitude of seed source, which can be modelled by a second-degree polynomial equation. The coefficients of determination were slightly higher for the polynomial than for the linear model, and the former was then selected to illustrate the trend (Table 5). A negative correlation was clearly observed for Timor, which comprised numerous subpopulations, and appeared to be similar in Flores, although the sample was smaller (Fig. 3). The small sample size on the other islands generally prevented observation of a specific trend within these islands. The survival rate was not well modelled by a polynomial equation, but the curve showed that a broad optimum for survival was reached for the altitude from 500 to $100 \mathrm{~m}$ (Fig. 3). This altitude corresponded to a temperature of $24{ }^{\circ} \mathrm{C}$, which was close to the mean annual temperature in Pointe-Noire and Loudima.

The hierarchical cluster analysis between subpopulations of the Timor island grouped the different subpopulations of E. urophylla according to their altitude (Fig. 4). Visual inspection of the dendrogram distinguished two or three groups corresponding, respectively, to a dissimilarity of $80 \%$ and $32 \%$. The partition in two groups was characterized by mean altitudes of 1300 and $940 \mathrm{~m}$ and 30 and 15 subpopulations. The partition in three groups was characterized by mean altitudes of 940, 1250, and $1460 \mathrm{~m}$ and 8, 22, and 15 subpopulations.

\section{Discussion}

\section{Variation of neutral markers}

The diversity parameters estimated in natural stands of E. urophylla $\left(n_{\mathrm{a}}=10-29\right.$ alleles/locus and expected heterozygosity $\left.\left(H_{\mathrm{e}}\right)=0.51-0.72\right)$ show that the species exhibits high microsatellite diversity compared with other forest tree species with similar patterns of seed dispersal and assessed with the same type of markers (Sanou et al. 2005).

Eucalyptus urophylla is distributed on small islands, which can reduce genetic diversity in certain cases (Frankham 1997); however, the species has similar genetic diversity to other $\mathrm{Eu}$ calyptus species distributed in a continuous range. This is demonstrated by the results of microsatellite diversity studies: $H_{\mathrm{e}}=0.86$ in Eucalyputs vernicosa Hook. f. (McGowen et al. 2001), $H_{\mathrm{e}}=0.84-0.91$ in Eucalyptus populnea F. Muell. (Holman et al. 2003), $H_{\mathrm{e}}=0.30-0.66$ in Eucalyptus curtisii J.T. Blake. \& C.T. White (Smith et al. 2003), and $H_{\mathrm{e}}=0.62$ in Eucalyptus globulus Labill. (Jones et al. 2002).

This high diversity reflects the biological traits and the evolutionary history of E. urophylla. The high diversity can be explained by a large effective population size, because high seed and pollen dispersal prevents clustering (Hamrick et al. 1992). This hypothesis is realistic, because pollen of Eucalyptus can be dispersed over long distances by birds or bats (McGoldrick and Mac Nally 1998).

For most of the populations, the positive and high fixation index indicates a marked deviation from Hardy-Weinberg expectations. Generally, Eucalyptus exhibits a random mat- 
Table 3. Performance of E. urophylla populations at two experimental sites in the Republic of Congo.

\begin{tabular}{|c|c|c|c|c|c|c|c|c|c|c|c|}
\hline \multirow[b]{2}{*}{ Trait } & \multicolumn{5}{|c|}{ Pointe-Noire forest station } & \multicolumn{5}{|c|}{ Loudima forest station } & \multirow[b]{2}{*}{$P^{a}$} \\
\hline & $N$ & Mean & Maximum & Minimum & $\mathrm{CV}(\%)$ & $N$ & Mean & Maximum & Minimum & $\mathrm{CV}(\%)$ & \\
\hline Height $(\mathrm{m})^{b}$ & 3759 & 10.4 & 19.5 & 1.5 & 29 & 5349 & 14.2 & 21.0 & 4.5 & 18 & 0.0001 \\
\hline Circumference $(\mathrm{cm})^{b}$ & 3759 & 26.1 & 63.0 & 8.0 & 27 & 5349 & 32.1 & 70.0 & 15.0 & 23 & 0.0001 \\
\hline $\mathrm{BA}_{\mathrm{i}}\left(\mathrm{cm}^{2}\right)^{b}$ & 3759 & 57.9 & 315.0 & 5.1 & 53 & 5349 & 86.0 & 389 & 18.0 & 44 & 0.0002 \\
\hline $\mathrm{BA}_{\mathrm{s}}\left(\mathrm{m}^{2} \cdot \mathrm{ha}^{-1}\right)^{c}$ & 320 & 7.3 & 15.9 & 0.4 & 37 & 562 & 10.6 & 0.8 & 20.6 & 30 & 0.0001 \\
\hline Survival $(\%)^{c}$ & 320 & 78 & 100 & 7 & 24 & 562 & 77 & 100 & 17 & 22 & 0.0681 \\
\hline
\end{tabular}

Note: Circumference is measured at breast height. $N$, total number of trees or plots; $\mathrm{CV}$, coefficient of variation; $\mathrm{BA}_{\mathrm{i}}$ : individual basal area; $\mathrm{BA}_{\mathrm{s}}$, stand basal area.

${ }^{a}$ Associated probability in the statistical test for the difference between the two site means.

${ }^{b}$ Values were calculated for individual trees.

${ }^{c}$ Values were calculated based on the plot means.

Table 4. Percentage of the total variance explained by different variance components and the value of $Q_{\mathrm{ST}}$ for growth and adaptive traits.

\begin{tabular}{|c|c|c|c|c|c|c|c|}
\hline \multirow[b]{2}{*}{ Trait } & \multicolumn{5}{|c|}{ Variance for each random effect $(\%)$} & \multirow[b]{2}{*}{$Q_{\mathrm{ST}}$} & \multirow[b]{2}{*}{ SE } \\
\hline & Population & Population $\times$ site & $\begin{array}{l}\text { Family } \\
\text { (population) }\end{array}$ & $\begin{array}{l}\text { Family } \\
(\text { population }) \times \text { site }\end{array}$ & Error & & \\
\hline \multicolumn{8}{|c|}{ Populations present in field trials (11 populations) } \\
\hline Height (total) & $43(0.048)$ & $21(0.0081)$ & $12(0.0001)$ & $8(0.0001)$ & 22 & 0.33 & 0.12 \\
\hline Circumference (total) & $34(0.0004)$ & $9(0.0001)$ & $20(0.0001)$ & $1(0.0127)$ & 37 & 0.17 & 0.08 \\
\hline Basal area (total) & $33(0.004)$ & $10(0.0001)$ & $13(0.0001)$ & $0(0.9913)$ & 44 & 0.07 & 0.04 \\
\hline Survival (total) & $14(0.0014)$ & $2(0.0256)$ & $24(0.0001)$ & $0(0.9838)$ & 60 & 0.25 & 0.10 \\
\hline \multicolumn{8}{|c|}{ Populations common to field trials and molecular analyses (10 populations) } \\
\hline Height (subsample) & $50(0.003)$ & $12(0.0001)$ & $3(0.1876)$ & $4(0.0457)$ & 31 & 0.68 & 0.21 \\
\hline Circumference (subsample) & $21(0.022)$ & $12(0.0004)$ & $9(0.0584)$ & $10(0.4124)$ & 49 & 0.22 & 0.09 \\
\hline Basal area (subsample) & $26(0.012)$ & $9(0.0001)$ & $6(0.0006)$ & $0(0.9899)$ & 59 & 0.37 & 0.16 \\
\hline Survival (subsample) & $5(0.0078)$ & $0(0.4643)$ & $30(0.0001)$ & $0(0.9775)$ & 65 & 0.02 & 0.01 \\
\hline
\end{tabular}

Note: Probabilities associated with the Fisher test of the analysis of variance are given in parentheses; SE, standard error. For each trait, comparison of estimates obtained with the whole sample of populations established in the field trial and the subsample composed of populations common to field and molecular analyses.

ing system (Byrne 1999; Butcher et al. 2002; Byrne et al. 1998; Elliott and Byrne 2003), but some studies have estimated an excess of homozygotes, e.g., for E. globulus (Jones et al. 2002), Eucalyptus marginata Donn ex Sm. (Wheeler et al. 2003), and E. populnea (Holman et al. 2003). Two factors can explain our results.

Firstly, $F_{\text {IS }}$ values for E. urophylla are likely to be overestimated, because we used seedlings raised in a nursery without selection, potentially including selfed seed. The mating system in many eucalyptus species allows self-pollination; although the outcrossing rate is about $80 \%$ for several species (Potts and Wiltshire 1997), inbred individuals are only present at the very first stage of life. The $F_{\text {IS }}$ estimates using adult trees in natural stands likely would have been lower because of selection against inbred individuals throughout the tree's lifespan (Potts and Wiltshire 1997).

Secondly, most of the populations in this study covered a wide geographic range and consisted of several possibly differentiated subpopulations. Therefore, the excess homozygosity detected in this study may be due to the Wahlund effect (apparent deficiency of heterozygotes due to the combining of data from subpopulations with large differences in allele frequency, even if Hardy-Weinberg proportions exist within each subpopulation). However, the high gene flow indicates absence of separation of subpopulations until recently, and the Wahlund effect hypothesis should be considered with caution.
The differentiation between E. urophylla populations was significantly different from 0 but very low $\left(F_{\mathrm{ST}}=0.04\right.$ for the 16 populations and $F_{\mathrm{ST}}=0.035$ for the 10 populations), showing that $96 \%$ of the variation assessed with microsatellites is present within the populations. Similar patterns of differentiation have been observed in other Eucalyptus species: using restriction frgament length polymorphisms, $F_{\mathrm{ST}}=0.045$ in E. marginata, (Wheeler et al. 2003), $F_{\mathrm{ST}}=$ 0.065-0.044 in Eucalyptus camaldulensis Dehnh. for the eastern and western regions (Butcher et al. 2002), $F_{\mathrm{ST}}=$ 0.065 in Eucalyptus occidentalis Endl. (Elliott and Byrne 2003 ) or using microsatellites, $F_{\text {IST }}=0.03$ in E. populnea (Holman et al. 2003) and $F_{\mathrm{ST}}=0.08$ in E. globulus (Jones et al. 2002). According to Potts and Wiltshire (1997), strong differentiation is observed in regionally distributed species with isolated populations; for example, $F_{\mathrm{ST}}=$ 0.136 in Eucalyptus angustissima F. Muell. (Elliott and Byrne 2004), $F_{\mathrm{ST}}=0.30$ in E. curtisii (Smith et al. 2003), and $F_{\mathrm{ST}}=0.19$ in Eucalyptus morrisbyi Brett (Jones et al. 2005).

The low differentiation observed in the present study is unexpected in an insular system; such species generally exhibit a high $F_{\mathrm{ST}}$, because the presence of oceanic barriers restricts gene flow between populations (Bottin et al. 2005). This apparent contradiction in the case of E. urophylla can be explained by a high migration rate compared with drift. Although barochory (i.e., seed dissemination by gravity) 
Fig. 3. Growth and adaptive performance of E. urophylla populations in the Congo versus altitude of the seed source in the natural range.

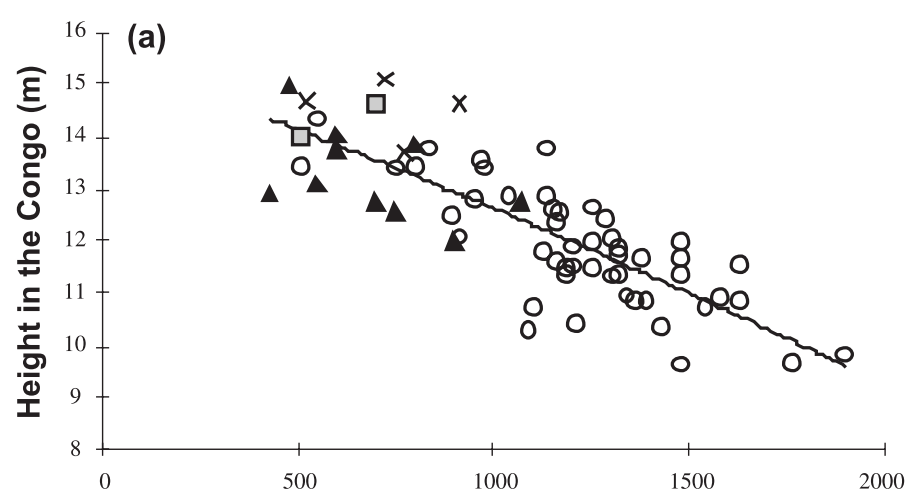

Altitude of seed source $(\mathrm{m})$

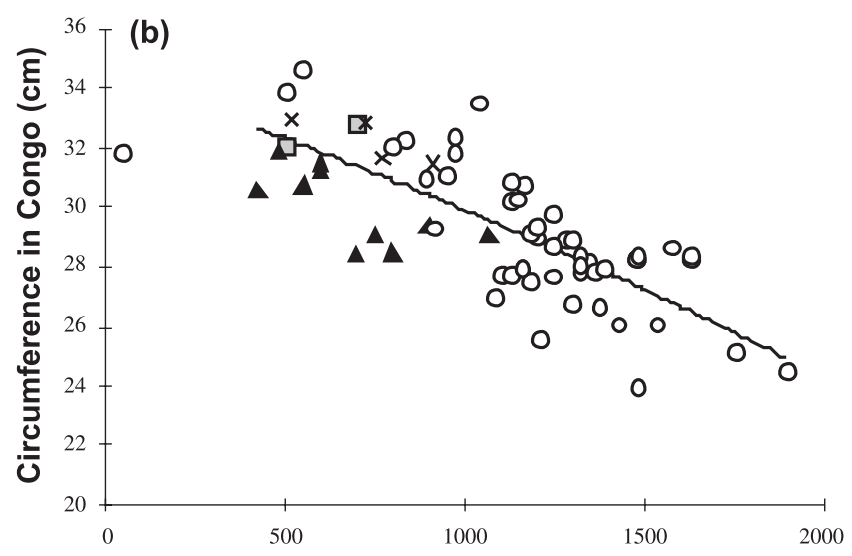

Altitude of seed source $(\mathrm{m})$

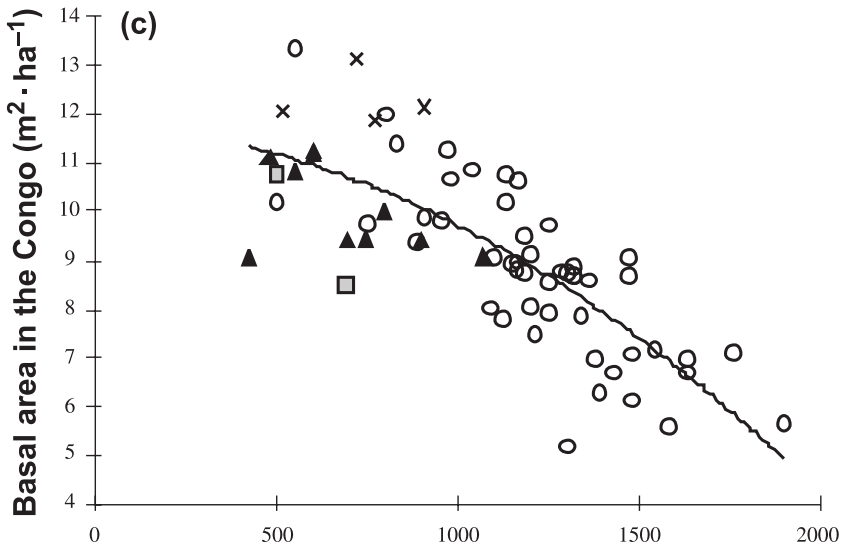

(c)

Altitude of seed source $(\mathrm{m})$

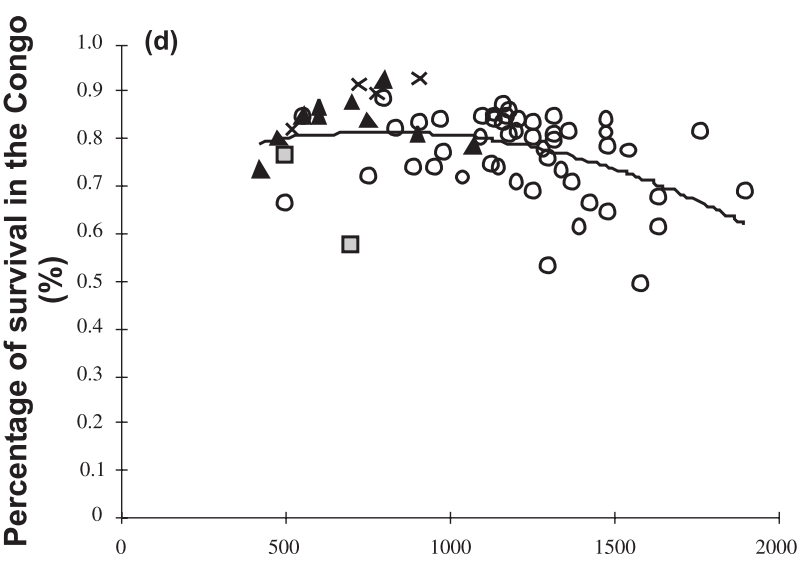

Altitude of seed source $(\mathrm{m})$

MODEL

Table 5. Coefficients of determination $\left(R^{2}\right)$ for the second-degree polynomial model explaining the variation of growth and adaptation in the Congo with abiotic variables characterizing the natural population in eastern Indonesia.

\begin{tabular}{lll}
\hline Traits & Altitude & Rainfall \\
\hline Height & 0.67 & 0.29 \\
Circumference & 0.59 & 0.16 \\
Basal area & 0.60 & 0.39 \\
Survival & 0.18 & 0.02 \\
\hline
\end{tabular}

seems to be predominant, pollen dispersal over long distances by birds and fruit bats can be very efficient and may have a significant impact in Eucalyptus species (House 1997; Richards 1995 cited in Butcher et al. 2002). This efficient gene flow was likely to be facilitated by the geographical connectivity of some islands during the last glaciations (20000 years B.P.) (Cannon and Manos 2003) or simply by their geographical proximity, some islands being separated by just a few kilometres.

\section{Variation in quantitative traits}

Our results show that E. urophylla populations established in the Congo exhibit wide variation, with height ranging from 5 to $18 \mathrm{~m}$; circumference, from 16.1 to $43.5 \mathrm{~cm}$; and survival rate, from $50 \%$ to $90 \%$. This high variation in growth and adaptive traits in Eucalyptus species has been observed in field trials of other species in the Congo, such as Eucalyptus cloeziana F. Muell. (Bouvet and Delwaulle 1983), and in other environments for other Eucalyptus species (Ginwal et al. 2004; Eldridge et al. 1993).

The variation within E. urophylla is characterized by the relatively large contribution of genetic components. The additive variance represents $38 \%-55 \%$ of the total variation in the 16-population sample and $32 \%-53 \%$ in the 10-population sample. The percentage of genetic variance among populations was particularly high for height (43\% and 50\%) and circumference (34\% and 21\%) (Table 4) compared with those usually observed in tree populations; in general, 20\%-30\% are observed for forest trees (Kremer 1994). This may have resulted from the strong adaptive variation between populations but also from the good control of the environment in the provenance trial of the Congo allowing 
Fig. 4. Hierarchical cluster analysis between subpopulations of the Timor island (each subpopulation is defined by the first three letters of the location name and by the altitude). The distance between two populations was defined as the Euclidean norm, and the dissimilarity between clusters based on this distance was defined using Ward's method (Ward 1963). The number of groups to build (partition a, three groups; partition b, two groups) was chosen by visual inspection of the cluster dendrogram. The mean altitude of each group is given at the base of the cluster.

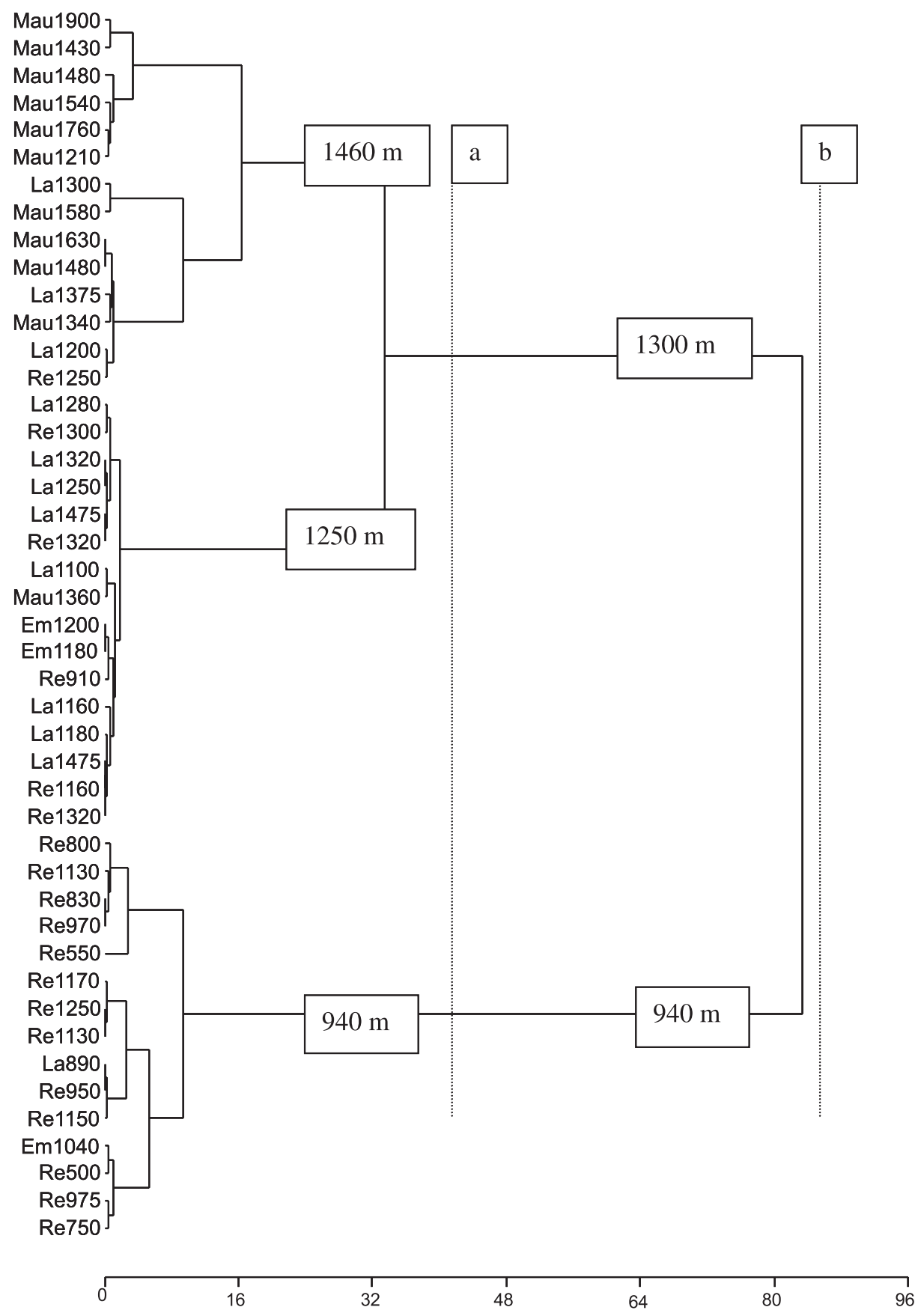

\section{Dissimilarity}

the genetic effects to be clearly expressed. It may also be that these trials simply included wider genetic diversity than is normally included in tree breeding populations.

\section{$F_{\mathrm{ST}}$ versus $\boldsymbol{Q}_{\mathrm{ST}}$}

We found significant differences between $F_{\mathrm{ST}}$ and $Q_{\mathrm{ST}}$ $(P=0.0001), Q_{\mathrm{ST}}$ being two to eight times higher than $F_{\mathrm{ST}}$ for the whole sample or the subsample common to field and molecular analyses. The higher value of $Q_{\mathrm{ST}}$ is generally observed in forest tree species such as pines (Yang et al. 1996), hardwood species (Lascoux et al. 1996; Kremer et al. 1997; Sanou et al. 2005), and other plants (Merilä and Crnokrak 2001; McKay and Latta 2002), but the ratio in this study is particularly pronounced. This could be explained by two 
points. Firstly the $Q_{\mathrm{ST}} / F_{\mathrm{ST}}$ ratio may be biased upward due to the high microsatellite mutation rate (Hedrick 1999). Simple sequence repeat (SSR) markers, although being mostly neutral, evolve faster than other nuclear loci and by a very different mutational mechanism. There may be problems associated with comparing $F_{\mathrm{ST}}$ values based on SSR polymorphisms with $Q_{\mathrm{ST}}$ values that are based on variation in (non-neutral) genes or regulatory regions that affect the trait of interest. Although the rate of evolution of the SSRs and nuclear genes may indeed not differ among populations, this problem should be addressed more comprehensively in future research to compare these two parameters. Secondly, our additive effects may not be purely additive but may include nonadditive effects, which can bias the $Q_{\mathrm{ST}} / F_{\mathrm{ST}}$ ratio (López-Fanjul et al. 2003). Although bias due to microsatellites should not be excluded, the quantitative genetic differentiation between E. urophylla populations suggested that directional selection is the main cause of differentiation in growth and adaptive traits. This natural selection may have occurred in response to the wide altitude variation (from 500 up to $2000 \mathrm{~m}$ in our sample but $3000 \mathrm{~m}$ in natural populations) leading to marked differences in rainfall, temperature and other abiotic factors. Altitude is likely to have led to local adaptation as is demonstrated through a strong negative relationship between altitude of seed source (subpopulation) and performance in the Congo (Table 5). This relationship between altitude and subpopulation performance was observed in other E. urophylla provenance trials established in different tropical countries (Eldridge et al. 1993).

This marked differentiation in quantitative traits among populations with a high gene flow can be explained by the linkage disequilibrium that decouples $F_{\mathrm{ST}}$ and $Q_{\mathrm{ST}}$. Latta (2003) has shown through simulation that covariances of allele (QTL allele) frequencies develop as traits evolve towards local optima. It would appear that, in species with high gene flow, divergence of polygenic traits among subpopulations is likely to be caused primarily by the covariance of allelic frequencies across populations rather than through high $F_{\mathrm{ST}}$ of quantitative trait loci. This phenomenon is all the more marked when the number of loci underlying quantitative traits is high.

\section{Clinal variation}

This pattern translates into a clinal variation, i.e., a continuous morphological or adaptive variation in relation to environmental variation. Similar strong clinal variation due to altitude has been observed for other Eucalyptus species, especially in the island of Tasmania where rugged topography results in rapid environmental change over short distances (Shaw et al. 1984; Potts and Reid 1985; Potts and Jackson 1986).

The cline observed for growth traits has also been noted for the morphological traits in E. urophylla. Martin and Cossalter (1976a) and Eldridge et al. (1993) observed leaf size and shape variation correlated with the altitude: smaller leaves were present at higher altitude. Variation of bark characteristics with altitude, especially the percentage of rough bark which increases with altitude, has also been observed in those populations (Martin and Cossalter 1976b).

Numerous genes seem to be affected by the selection pressure due to altitudinal variation in E. urophylla. This result constitutes critical information for the implementation of a strategy of in situ management of genetic resources.

\section{Implications for management of genetic resources}

The importance of plantations is increasing in the world because of the pressure to reduce the role of natural forest in wood production. Tropical Eucalyptus species such as E. urophylla have some advantages in providing wood and in reclaiming abandoned land unacceptable for agriculture (Bouvet 1999). However, human activities such as clearing for agriculture or overexploitation are threatening the natural stands of E. urophylla (Eldridge et al. 1993), and there is an urgent need for in situ and ex situ conservation of genetic resources of this species.

Based on our results, the approach elaborated by Crandall et al. (2000), who argue that incorporating ecological data and genetic variation of adaptive significance is more relevant for conservation than molecular information alone, can be used to define conservation and management units for E. urophylla. A similar principle was proposed for forest trees by Bekessy et al. (2003) and Cavers et al. (2004) who suggested that in defining management units most emphasis should be placed on data that reflect expressed genes and adaptive traits. Our data show that there is evidence for population differentiation owing to natural selection but not owing to restricted gene flow. Therefore, we suggest the use of the altitude of seed source as an important principle for in situ or ex situ management of E. urophylla genetic resources. As an example, using the clustering analysis (Fig. 4), different ways of grouping the populations of the Timor island can be suggested. According to the means available to implement a strategy of management of genetic resources, two options can be suggested: the first consists in defining the management units at altitudes of 1300 and $900 \mathrm{~m}$, and the second, at altitudes of 900, 1200, and $1500 \mathrm{~m}$. The number of management units may vary at each altitude, depending on such things as the soil variation within each altitude, the characteristics of the E. urophylla stands, and the fragmentation of the populations. This principle could be limited to a small number of islands becuase of the low differentiation among islands.

\section{Acknowledgements}

We are grateful to UR2PI (Unité de recherche sur le productivité des plantations industrielles) of the Republic of Congo in Pointe-Noire and Loudima, especially to the monitoring team, for providing valuable assistance and data collection in these two experiments. We are very grateful for the technical assistance of the staff of the forest molecular laboratory of CIRAD Research Unit "Genetic Diversity and Breeding of Forest Tree Species" and especially to Mireille Poitel for the implementation of nuclear microsatellites. We are grateful for the technical assistance of the staff of the genotyping platform of the Montpellier Languedoc-Roussillon Genopole ${ }^{\circledR}$ located in the UMR DAP of CIRAD.

\section{References}

Becker, W.A. 1984. Manual of quantitative genetics. 4th ed. Academic Entreprises, Pulman, Wash. 
Bekessy, S.A., Ennos, R.A., Burgman, M.A., Newton, A.C., and Ades, P.K. 2003. Neutral DNA markers fail to detect divergence in an ecologically important trait. Biol. Conserv. 110: 267-285. doi:10.1016/S0006-3207(02)00225-2.

Belkhir, K., Borsa, P., Chikhi, L., Raufaste, N., and Bonhomme, F. 1996-2004 GENETIX 4.05, logiciel sous Windows TM pour la génétique des populations. Laboratoire Génome, Populations, Interactions, CNRS UMR 5171, Université de Montpellier II, Montpellier, France.

Bottin, L., Verhaegen, D., Tassin, J., Olivieri, I., Vaillant, A., and Bouvet, J.M. 2005. Genetic diversity and population structure of an insular tree, Santalum austrocaledonicum, in New Caledonian archipelago. Mol. Ecol. 14: 1979-1989. doi:10.1111/j.1365294X.2005.02576.x. PMID:15910320.

Bousquet, J., Simon, L., and Lalonde, M. 1990. DNA amplification from vegetative and sexual tissues of trees using polymerase chain reaction. Can. J. For. Res. 20: 254-257.

Bouvet, J.-M. 1999. Les plantations d'Eucalyptus : évolutions récentes et perspectives. Flamboyant, 49: 4-15.

Bouvet, J.M., and Delwaulle, J.C. 1983. Introduction d'Eucalyptus cloeziana au Congo. Bois For. Trop. 200: 7-20.

Brondani, R.P.V., Brondani, C., Tarchini, R., and Grattapaglia, D. 1998. Development, characterization and mapping of microsatellites markers in Eucalyptus grandis and E. urophylla. Theor. Appl. Genet. 97: 816-827. doi:10.1007/s001220050961.

Butcher, P.A., Otero, A., McDonald, M.W., and Moran, G.F. 2002. Nuclear RFLP variation in Eucalyptus camaldulensis Dehnh. from northern Australia. Heredity, 88: 402-412. doi:10.1038/sj. hdy.6800074. PMID:11986878.

Byrne, M. 1999. High genetic identities between three oil mallee taxa, Eucalyptus kochii ssp. kochii, ssp. plenissima and E. horistes, based on nuclear RFLP analysis. Heredity, 82: 205-211. doi:10.1038/sj.hdy.6884740.

Byrne, M., Parrish, T.L., and Moran, G.F. 1998. Nuclear RFLP diversity in Eucalyptus nitens. Heredity, 81: 225-233. doi:10. 1038/sj.hdy.6883860.

Cannon, C.H., and Manos, P.S. 2003. Phylogeography of the Southeast Asian stone oaks (Lithocarpus). J. Biogeogr. 30: 211226. doi:10.1046/j.1365-2699.2003.00829.x.

Cavalli-Sforza, L.L., and Edwards, A.W.F. 1967. Phylogenetic analysis: models and estimation procedures. Am. J. Hum. Genet. 19: 233-257. PMID:6026583.

Cavers, S., Navarro, C., and Lowe, A.J. 2004. Targeting genetic resource conservation in widespread species: a case study of $\mathrm{Ce}$ drela odorata L. For. Ecol. Manage. 197: 285-294. doi:10. 1016/j.foreco.2004.05.019.

Crandall, K.A., Bininda-Emonds, O.R.P., Mace, G.M., and Wayne, R.K. 2000. Considering evolutionary processes in conservation biology. Trends Ecol. Evol. 15: 290-295. doi:10.1016/S01695347(00)01876-0. PMID:10856956.

Ducousso, A., Louvet, J.-M., Faucher, M., Legroux, P., Jarret, P., and Kremer, A. 2004. Révision des régions de provenance et peuplements sélectionnés: le cas des chênes pédonculé et sessile. In Diversité génétique des arbres forestiers: un enjeu de gestion ordinaire. Office National des Forêts, Paris, France. Rendezvous Tech. Off. Natl. For. Hors-Ser. No. 1. pp. 33-42.

Eldridge, K., Davidson, J., Harwood, C., and van Wyk, G. 1993. Eucalyptus urophylla. In Eucalypt domestication and breeding. Clarendon Press, Oxford. pp. 144-152.

Elliott, C., and Byrne, M. 2003. Genetic diversity within and between natural populations of Eucalyptus occidentalis (Myrtaceae). Silvae Genet. 52: 169-173.

Elliott, C.P., and Byrne, M. 2004. Phylogenetics and the conservation of rare taxa in the Eucalyptus angustissima complex in
Western Australia. Conserv. Genet. 5: 39-47. doi:10.1023/ B:COGE.0000014063.56405.93.

Felsenstein, J. 1993. PHYLIP (phylogeny inference package), version 3.65 edition. Department of Genome Sciences, University of Washington, Seattle, Wash.

Frankham, R. 1997. Do island populations have less genetic variation than mainland populations? Heredity, 78: 311-327. doi:10. 1038/sj.hdy.6880980. PMID:9119706.

Frankham, R., Ballou, J.D., and Briscoe, D.A. 2002 Introduction to conservation genetics. Cambridge University Press, Cambridge, UK.

Ginwal, H.S., Kumar, P., Sharma, V.K., Mandal, A.K., and Hardwood, C.E. 2004. Genetic variability and early growth performance of Eucalyptus tereticornis Sm. in provenance cum progeny trials in India. Silvae Genet. 53: 148-153.

Hamrick, J.L., Godt, M.J.W., and Sherman-Broyles, S.L. 1992. Factors influencing levels of genetic diversity in woody plant species. New For. 6: 95-124.

Hedrick, P.W. 1999. Perspective: highly variable loci and their interpretation in evolution and conservation. Evolution, 53: 313 318. doi: $10.2307 / 2640768$.

Holman, J.E., Hughes, J.M., and Fensham, R.J. 2003. A morphological cline in Eucalyptus: a genetic perspective. Mol. Ecol. 12: 3013-3025. doi:10.1046/j.1365-294X.2003.01970.x. PMID: 14629382 .

House, S.M. 1997. Reproductive biology of eucalypts. In Eucalypt ecology: individuals to ecosystems. Edited by J.E. Williams and J.C.Z. Woinarski. Cambridge University Press, Cambridge, UK. pp. 30-55.

Jones, R.C., Steane, D.A., Potts, B.M., and Vaillancourt, R.E. 2002. Microsatellite and morphological analysis of Eucalyptus globulus populations. Can. J. For. Res. 32: 59-66. doi:10.1139/x01-172.

Jones, R.C., McKinnon, G.E., Potts, B.M., and Vaillancourt, R.E. 2005. Genetic diversity and mating system of an endangered tree Eucalyptus morrisbyi. Aust. J. Bot. 53: 367-377. doi:10. 1071/BT04182.

Kleinschmit, J.R.G., Kownatzki, D., and Gregorius, H.-R. 2004. Adaptational characteristics of autochthonous populations consequences for provenance delineation. For. Ecol. Manage. 197: 213-224. doi:10.1016/j.foreco.2004.05.037.

Kremer, A. 1994. Diversité génétique et variabilité des caractères phénotypiqueschez les arbres forestriers. Genet. Sel. Evol. 26: 105-123.

Kremer, A., Zanetto, A., and Ducousso, A. 1997. Multilocus and multitrait measures of differentiation for gene markers and phenotypic traits. Genetics, 145: 1229-1241. PMID:9093871.

Lascoux, M., Thorsén, J., and Gullberg, U. 1996. Population structure of riparian willow species, Salix viminalis L. Genet. Res. 68: $45-54$.

Latta, R.G. 2004. Gene flow, adaptive population divergence and comparative population structure across loci. New Phytol. 161: 51-58. doi:10.1046/j.1469-8137.2003.00920.x.

López-Fanjul, C., Fernández, A., and Toro, M.A. 2003. The effect of neutral nonadditive gene action on the quantitative index of population divergence. Genetics, 164: 1627-1633. PMID: 12930766.

McGoldrick, J.M., and Mac Nally, R. 1998. Impact of flowering on bird community dynamics in some central Victorian eucalypt forests. Ecol. Res. 13: 125-139. doi:10.1046/j.1440-1703.1998. 00252.x.

McGowen, M.H., Wiltshire, R.J.E., Potts, B.M., and Vaillancourt, R.E. 2001. The origin of Eucalyptus vernicosa, a unique shrub eucalypt. Biol. J. Linn. Soc. 74: 397-405. doi:10.1006/bij1.2001. 0588 . 
McKay, J.K., and Latta, R.G. 2002. Adaptive population divergence: markers, QTL and traits. Trends Ecol. Evol. 17: 285291. doi:10.1016/S0169-5347(02)02478-3.

Mantel, N. 1967. The detection of disease clustering and a generalized regression approach. Cancer Res. 27: 209-220. PMID: 6018555.

Martin, B., and Cossalter, C. 1976a. Les Eucalyptus des îles de la Sonde. Partie 1. Bois For. Trop. 165: 3-20.

Martin, B., and Cossalter, C. 1976b. Les Eucalyptus des îles de la Sonde. Partie 2. Bois For. Trop. 166: 3-22.

Martin, B., and Cossalter, C. 1976c. Les Eucalyptus des îles de la Sonde. Partie 3. Bois For. Trop. 167: 3-24.

Merilä, J., and Crnokrak, P. 2001. Comparison of genetic differentiation at marker loci and quantitative traits. J. Evol. Biol. 14: 892-903. doi:10.1046/j.1420-9101.2001.00348.x.

Nei, M. 1987. Molecular evolutionary genetics. Columbia University Press, New York. pp. 1-512.

Page, R.D.M. 1996. TREEVIEW: an application to display phylogenetic trees on personal computers. Comput. Appl. Biosci. 12: 357-358. PMID:8902363.

Potts, B.M., and Jackson, W.D. 1986. Evolutionary processes in the Tasmanian high altitude eucalypts. In Flora and fauna of alpine Australasia. Ages and origins. Edited by B.A. Barlow. Australian Systematic Botanical Scoiety and Commonwealth Scientific and Industrial Research Organization, Canberra, Australia. pp. 511-527.

Potts, B.M., and Reid, J.B. 1985. Variation in the Eucalyptus gunniiarcheri complex. II. The origin of variation. Aust. J. Bot. 33: 519-541. doi:10.1071/BT9850519.

Potts, B.M., and Wiltshire, R.J.E. 1997. Eucalypt genetics and genecology. In Eucalypt ecology: individuals to ecosystems. Edited by J. Williams and J. Woinarski. Cambridge University Press, Cambridge, UK. pp. 56-91.

Saint-Laurent, R., Legault, M., and Bernatchez, L. 2003. Divergent selection maintains adaptive differentiation despite high gene flow between sympatric rainbow smelt ecotypes (Osmerus mordax Mitchill). Mol. Ecol. 12: 315-330. doi:10.1046/j.1365294X.2003.01735.x. PMID:12535084.

Saitou, N., and Nei, M. 1987. The neighbor-joining method: a new method for reconstructing phylogenetic trees. Mol. Biol. Evol. 4: 406-425. PMID:3447015.
Sanou, H., Lovett, P.N., and Bouvet, J.M. 2005. Comparison of quantitative and molecular variation in agroforestry populations of the shea tree (Vitellaria paradoxa C.F. Gaertn) in Mali. Mol. Ecol. 14: 2601-2610. doi:10.1111/j.1365-294X.2005.02601.x. PMID:15969738.

SAS Institute Inc. 1990. SAS/STAT ${ }^{\circledR}$ user's guide, release 6.03 edition. SAS institute Inc., Cary, N.C.

Searle, S.R., Casella, G., and McCullock, C.E. 1992. Variance components. John Wiley \& Sons Inc., New York. pp. 1-501.

Shaw, M.J., Potts, B.M., and Reid, J.B. 1984. Variation within and between Eucalyptus nitida Hook.F., and E. coccifera Hook.F. Aust. J. Bot. 32: 641-654. doi:10.1071/BT9840641.

Smith, S., Hughes, J., and Wardell-Johnson, G. 2003. High population differentiation and extensive clonality in a rare mallee eucalypt: Eucalyptus curtisii. Conservation genetics of a rare mallee eucalypt. Conserv. Genet. 4: 289-300. doi:10.1023/ A:1024077315820.

Van der Nest, M.A., Steenkamp, E.T., Wingfield, B.D., and Wingfield, M.J. 2000. Development of simple sequence repeat (SSR) markers in Eucalyptus from amplified inter-simple sequence repeats (ISSR). Plant Breed. 119: 433-436. doi:10.1046/j.14390523.2000.00515.x.

Vigneron, P., and Bouvet, J.-M. 1997. Eucalyptus. In Breeding of tropical plants. Edited by A. Charrier, M. Jacquot, S. Hamon, and D. Nicolas. CIRAD, Orstom, Montpellier, France. Collection Repères. pp. 267-290.

Ward, J.H. 1963. Hierarchical grouping to optimize an objective function. J. Am. Stat. Assoc. 58: 236-244. doi:10.2307/2282967.

Weir, B.S., and Cockerham, C.C. 1984. Estimating F-statistics for the analysis of population structure. Evolution, 38: 1358-1370. doi: $10.2307 / 2408641$.

Wheeler, M.A., Byrne, M., and McComb, J.A. 2003. Little genetic differentiation within the dominant forest tree, Eucalyptus marginata (Myrtaceae) of south-western Australia. Silvae Genet. 52: 254-259.

Wright, S. 1951. The genetical structure of populations. Ann. Eugen. 15: 323-354.

Yang, R.-C., Yeh, F.C., and Yanchuk, A.D. 1996. A comparison of isozyme and quantitative genetic variation in Pinus contorta ssp. latifolia by $F_{\mathrm{ST}}$. Genetics, 142: 1045-1052. PMID:8849910. 